ville, it nevertheless is the most southern part of western Texas and of the entire arid southwestern part of the country, and the salient which it occupies in the bend of the river carries it deep into adjacent Mexican territory on three sides, with its extremity almost as far south as the middle of Lower California. The extreme aridity of the climate, the average annual rainfall being in most parts less than fifteen inches, and the great diversity of soil and geological formation, as well as the considerable range in elevation are of course dominant factors in accounting for the varied and unusual flora. Due to the sparsity of settlement and the impossibility of agricultural improvement over nearly all of the area it remains almost entirely in a state of nature, a condition that is not likely to be changed materially for a long while, at least under any conditions that we can foresee at present. The Chisos Mountains, situated as they are near the southern extremity of the area and close to the river that forms the international boundary, are widely separated by great stretches of desert from any region of similar topography. The higher peaks of the mountains here rise from 1000 to 1800 meters above the surrounding plains, and this difference in elevation, together with the protection afforded by the deep canyons and the somewhat greater amount of moisture received in the form of showers and mist from passing clouds which they intercept, furnishes favorable habitats to many plants not found elsewhere in the United States, and to others that are known only from stations hundreds of miles away.

It is not surprising, therefore, that every expedition and all collectors who have gone into this region have been rewarded by new and interesting discoveries, and it is reasonably certain that more thorough and systematic exploration would result in many others. The inaccessibility of the region and the considerable difficulties still to be encountered in traveling through it, some of which are indicated in this narrative, make it improbable that the flora will be known in complete detail for many years to come.

\title{
LEAVES FROM A COLLECTOR'S NOTE BOOK
}

\section{Ernest J. Palmer}

$$
\text { Page, Okla., April 14th, } 1928 .
$$

While coming down the steep slopes of Rich Mountain this morning 1 found several shrubby specimens of Cotinus americanus in a rocky ravine, 75 or 80 meters above the creek valley.

This rare and interesting tree was originally discovered by Thomas Nuttall on a bluff of Grand River, or as it is now called the Neosho River, thirty or forty miles above its confluence with the Arkansas. Since that time it has turned up in a number of isolated localities in the Ozark region of Missouri and Arkansas, as well as in northern Alabama and western Texas, but so far as I know it had not been collected again in Oklahoma. 
Nuttall's station is north of the Arkansas River and about 100 miles from here.

In the Ozark region the Smoke-tree seems to be limited to rocky bluffs and hills along the valleys of the Arkansas and White Rivers. It is most abundant and of the largest size on the dolomite bluffs and adjacent bald knobs along White River, where it sometimes becomes a tree ten meters or more in height and with a trunk diameter of over three decimeters. In the Arkansas River valley it grows along high sandstone bluffs, with a west or south exposure, where it was first found several years ago near Van Buren by Mr. G. M. Brown.

\section{Houston, Texas, April 15th.}

This morning I accompanied Mr. Edward Teas to his nurseries in Conroe County. The plantations are located in a clearing of typical piney woods, as it is known in this section. The soil is a fine sandy loam rather rich in humus when first cleared. The principal forest growth is Old Field Pine (Pinus taeda) interspersed with a large variety of deciduous trees and shrubs.

After we had inspected some of the interesting collection of trees in the nursery and admired the brilliant display of Verbenas, Bluebonnets and other bedded plants, Mr. Teas conducted us through the woods to a little bayou, where last year he discovered the Choke Cherry (Aronia arbutifolia f. macrophylla). We found several of these shrubs growing along the banks, the plants being already out of bloom but with young fruit.

This is the third station so far found in Texas for the southern form of this typically eastern American genus, and it considerably extends the westward range. The other stations are near Bland Lake, San Augustine County, where the type of the large-leaved form was found, the plants there attaining a height of from five to seven meters and being somewhat arborescent; and along the borders of a sandy bog, in the suburbs of Texarkana, just within the state line.

Sanderson, Texas, April 25th.

On several previous trips to and from western Texas I have looked eagerly down into the deep canyon of the Pecos River, where the Southern Pacific Railroad crosses it on the high bridge. The bridge is more than 330 feet above the river, and with the canyon forms one of the principal scenic features of the rather monotonous and dreary stretch of arid plain and desert between Del Rio and Alpine.

Leaving most of my outfit at Sanderson I boarded a local train yesterday morning and got off at the flag stop, known as Viaduct, on the west side of the river, where we arrived shortly after noon. My entire equipment consisted of plant press, kodak and a little knapsack, containing a light lunch and a few indispensible collecting supplies; and as the country is but sparsely inhabited and without any accommodations for travelers, I felt a slight thrill of adventure in thus plunging into the unknown. This historic 
river was formerly supposed to mark the last boundary of civilization, and "the law west of the Pecos" was the law of the gun, the strong arm and Judge Lynch.

The river at this point has excavated a deep narrow canyon in the Edwards limestone, a heavily-bedded formation of the Comanchean series. The canyon walls are in most places almost perpendicular, rising to a height of from $\mathbf{8 0}$ to $\mathbf{1 0 0}$ meters above the bed of the river, and I went some distance below the bridge looking for a ravine or place where it would be possible to descend to the lower level. Not finding this I went back for nearly a mile along the railway, following a side canyon, before I found a place to get down into it.

The country was extremely dry and no herbaceous vegetation was apparent on the rocky plains above the canyon. The most conspicuous plants were Yuccas and Opuntias of several species, Gregg's Ash (Fraxinus Greggii) and the curious Candlewood or Ocotillo of the Mexicans (Fouquieria splendens) with its straight simple branches, two or three meters high, surmounted by a tuft of brilliant scarlet flowers, suggesting, I suppose, the popular name from a fancied resemblance to the flame of a candle. Along rocky ledges bordering the cliffs the Resurrection-plants (Selaginella lepidophylla) were very abundant, and there were dry tufts of several ferns, but with no sign of recent growth.

Descending with some difficulty into the canyon, which at this point was 50 or 60 feet deep, a striking change in the vegetation was apparent. There was no water in the canyon and scarcely any herbaceous growth, but a variety of trees and shrubs were flourishing, many of them being in flower or fruit. Amongst the most conspicuous were Quercus annulata, Q. Vaseyana, Celtis reticulata, C. laevigata var. texana, Acacia Roemeriana, A. Berlandieri, Sophora secundiflora, Leucaena retusa, Ungnadia speciosa, Rhus virens, Forestiera neomexicana and Cercis reniformis. Lucaena and the two species of Acacia bore a profusion of flowers and were hosts to many insects. The broad leaves of the Texas Red-bud (Cercis reniformis) were a striking contrast to the small or dissected foliage of most of the other plants, but it was by no means common. The Mexican Buckeye (Ungnadia speciosa) and several of the other trees and shrubs were also in bloom.

Huge detached masses and boulders of the limestone were piled up in the canyon, in places almost obstructing passage, and there were evidences in the form of drift left high on the walls and trees of the great floods that have rushed through it in times of torrential rain. Karvinskia Humboldtiana was abundant near the river and here also I found Prunus minutiflora.

Proceeding into the main canyon I passed under the high bridge and began making my way down the bank of the river, which is here lined with a dense growth of small trees and chaparral shrubs, rendering progress in places anything but easy. Salix nigra var. Lindheimeri and Baccharis glutinosa were abundant near the normal water line and also great clumps 
of the cane-like grass, Arundo Donax, and the smooth-barked shrub or tree, Nicotiana glauca. The two last mentioned are both introduced plants, the former coming from the Old World and the latter from South America. This curious arborescent representative of the Tobacco family is thoroughly established and is abundant along the lower courses of the Pecos, the Rio Grande and other streams of southwestern Texas.

On the higher banks and talus slopes between the river and the canyon walls the shrubby growth is often dense but it varies in character according to the amount of exposure or the protection afforded. A zone of typical chaparral occupies the intermediate ground in many places. This is quite similar in composition and appearance to the growth found along the coastal plain to the south and east, but the conditions here are too arid for it to become established beyond the protected canyon. Amongst the commonest shrubs of this formation are Celtis pallida, Colubrina texensis, Condalia obtusifolia, Porlieria angustifolia and several species of Acacia and Mimosa. Farther up, on somewhat exposed rocky slopes and ledges, this association gives place to a more xerophytic one, in which Ephedra antisyphilitica, Mozinna sessilifolia, a curious little Euphorbiaceous shrub locally known as Leatherwood, the Candlewood and several species of $O$ puntia and $\boldsymbol{Y}$ ucca are most common. Near the base of the high cliffs, that afford a measure of protection from the scorching sun, are found the Wild China-tree or Soapberry (Sapindus Drummondii), the Mexican Buckeye (Ungnadia speciosa), the evergreen Sumach (Rhus virens) and the Cat Brier (Smilax Bona-nox). In one of the small ravines below the canyon wall $I$ also found an abundant growth of a scandent species of Poison Ivy (Toxicodendron biternatum Greene), which was climbing to a height of several meters on the face of the limestone cliff and into small trees and shrubs. The deeply-cut foliage of this plant gives it a distinctive and handsome appearance. I remember having found it also, several years ago, in the canyon of Devil's River. Along the base of the bluff a little lower down a woody Cardiospermum was growing, but it was not yet in flower.

As the day was hot and I had not come upon a spring I was at last constrained to try the river water, which was clear and flowing, but one taste of this sufficed, as it was extremely brackish and bitter.

Before leaving Sanderson, and also from a chance acquaintance on the train, I had made inquiry and been told that there was a white family living in a ranch house near the highway bridge, some miles below the railway, and I had hoped to find lodging there for the night. Towards evening I came in sight of the bridge and little house, and here I found an old Mexican cooking supper over a camp fire. He spoke fairly good English and in answer to my inquiries he told me that the house was vacant except for some highway workers who were camping there, and with whom he was working. He gave me to understand that he was in charge of the place and said that I might stay there for the night if I wished, and he also 
invited me to have supper. Seeing no alternative except sleeping out in the canyon, where, aside from the discomfort, there might have been some danger from snakes or scorpions, I readily accepted his hospitality. The meal consisted of a stew of bacon, onions and chili pepper, very hot according to the Mexican taste, with black coffee and a sort of bread in the form of cakes or thin loaves baked in a covered skillet over the camp fire. During the meal an old white man and his son joined us and a number of other Mexicans came up and camped at a little distance. To my further inquiries about lodgings the "Americano" did not at first seem as responsive or hospitably inclined as was my Mexican host, and I could not determine which of them was really in charge of the camp. The old man seemed rather suspiciously curious about my business and reason for appearing there, which perhaps was not altogether unnatural. The Mexican, however, did not seem to share this suspicion but appeared to regard it as quite natural that I should be collecting plants, and he looked over my specimens with interest, telling me the Mexican names of most of them. It is a curious fact that the ignorant American usually seems less inclined to take an interest in nature and is not so well informed regarding natural objects and places of interest in his locality as are the men of more primitive races.

After supper cigarettes and conversation soon put us on good terms, and they assigned me the best accomodations they had - an old wire cot without bedding in a screened porch of the little house. The two white men occupied an adjoining room, sleeping on the floor, and the Mexican found quarters elsewhere. I slept with a feeling of perfect security, inspired by my knowledge of the country and the people, although not with the greatest comfort. At the earliest sign of daylight we were up and soon had breakfast, consisting again of black coffee and bread with the addition of "frijoles," cooked in the Mexican fashion. Taking leave of my friends of the camp I started to walk down to the Rio Grande, which they told me was less than a mile below. As an illustration of the hospitable customs of the country, I was unable to persuade either the white men or the Mexican to accept any compensation for my lodging and meals.

Below the bridge the valley begins to widen and several additional species of trees and shrubs appear. The chaparral occupied the higher portions, and in the deeper alluvial ground Fraxinus Berlandieriana, Prosopis juliflora, Salix nigra var. Lindheimeri and a shrubby form of the Sand Bar Willow (Salix longifolia var. angustissima) were growing.

One of the most striking plants of the chaparral is the Soap-bush, as it is known in southern Texas (Porlieria angustifolia), of the Lignum-vitae family (Zygophyllaceae). This was quite common in dryer situations, sometimes growing as a low shrub with stout crooked branches spreading near the ground, apparently due to a sort of pruning of the young growth by grazing animals; elsewhere it attained a height of four or five meters with numerous stout and erect stems. Some of the bushes had a profusion of the deep violet flowers and some half developed seed pods. 
The mouth of the canyon is several hundred yards in width and is bounded by bold promontories that continue as a line of high bluffs along the American side of the Rio Grande. The locality is much frequented by fishermen and campers, although none were there at the time of my visit, and there were signs of a lively international trade, in the form of broken and empty bottles scattered in great quantities through the chaparral. The Mexican side of the river was low and covered in places with thickets of Willows, Baccharis glutinosa, Arundo Donax and similar growth. My friends of the road camp had warned me that there had recently been some shooting across the river, and I was somewhat wary of exposing myself there, although there probably was really little danger except to such as were engaged in contraband traffic or the excesses that grow out of it.

Going back along the east bank of the Pecos I decided to cross the river some distance above the highway bridge. This I easily accomplished by removing my boots and wading across at a shallow point, the water being nowhere more than knee deep. With some difficulty I climbed the bluffs and came out upon the highway and the dry rocky plain that it traverses. Here I took several photographs of the desert flora, of which Yuccas, Opuntias and the Candle Bush were conspicuous features. A little farther on I was overtaken by a party of fishermen, whom I had encountered in going down the river on the previous day, and I rode with them to the little station of Shumla where we enjoyed the luxury of cold drinks and lunch.

Having three or four hours to wait here for the train I spent it in exploring another deep little canyon leading down to the Rio Grande, which is less than a mile from the station. This was in all respects similar to the one I had first entered on the previous day, but it added several woody plants not seen in the former. Bumelia texana was growing here as a shrub less than two meters high, and all of the plants were badly infested by some insect that caused a swelling of the young branchlets where eggs were deposited. In the protection of the high perpendicular bluffs that formed the canyon walls some of the shrubs attained the dimensions of trees, although shrubby in form. Specimens of Quercus Vaseyana were noted fully ten meters in height and with trunks three decimeters in diameter. Lencaena retusa grew to a height of eight or nine meters and Ungnadia speciosa, Sophora secundiflora and Porlieria angustifolia were fully six meters high. Smilax Bona-nox and Vitis Longii were climbing in trees and shrubs close to the canyon walls and Porophyllum scoparium was growing in clefts of the limestone.

Uvalde, Texas, April 30th. This flourishing little city, one of the prettiest and most attractive in southwestern Texas, is situated near the head of the Leana River, a tributary of the Frio. It is only a small intermittent stream here, with a few water holes at intervals along its course, some of which are fed by springs that seep through the clay or gravel banks. The Nueces River 
flows a few miles to the west, and although it also is often dry in part of its course, it is one of the most important rivers in this part of the state.

Today I followed the Leana for several miles below the town. A considerable tract has been set aside for a park, and this is largely in a state of nature except for the clearing away of undergrowth and the opening of roads. Live Oak and Pecan are the principal trees, with some Mesquite, Hackberry and Cedar Elm (Ulmus crassifolia) in the more open parts.

For some distance down the river the banks are low, with occasional bluffs only a few meters in height, cut through the soft conglomerate of the Uvalde formation, a diluvial deposit of comparatively recent geologic age. Beyond the meandering rocky bed of the stream alluvial flood plains have scarcely begun to develop. Close to the river I examined some rather large trees of Celtis laevigata var. texana and Morus rubra. Live Oaks overhung the banks in most places, often festooned with Grape vines (Vitis Berlandieri), and Rhus Toxicodendron and R. rhomboidea are common shrubs. Usually the Pecan is the most abundant tree, and it often attains a height of 15 or 20 meters. Along wet banks and the margins of water holes there are some fine beds of the Maidenhair and Shield ferns (Adiantum Capillus-Veneris and Dryopteris patens) and two species of Water Pimpernel (Samolus floribundus and S. ebracteatus). A little distance back from the stream the semi-arid vegetation holds sway, with a variety of spiny shrubs and small trees. Yuccas, Cacti, Mesquite and the Huajilla (pronounced Waheyah) are common, the last often being the dominant plant in rocky ground. It is said to furnish excellent forage for sheep and goats, and I was told by ranchmen that they attribute the superior quality of the mohair produced here to the abundance of this shrub. The fragrant flowers of this species of Acacia (A. Berlandieri) are also of great value to the apiarists, who have developed an industry of considerable local importance.

\section{May 1st.}

Chalk Bluff, about 14 miles northwest of Uvalde, is one of the largest bluffs in this vicinity and probably along the whole course of the Nueces River. There is no settlement or village at this point, but a club house is located nearfor the accomodation of campers and fishermen. The riverhere has cut through the horizontal beds of Comanchean limestone, which are exposed in the bluff, rising to a maximum height of perhaps more than 300 feet (100 meters) above the stream, and extending along it for nearly a quarter of a mile. The exposure is mainly towards the east. On the opposite side the strata have been broken down and removed, perhaps owing to a difference in composition due to faulting.

I had made two visits to this locality several years ago, and on the first occasion found a large Cottonwood tree, which was later taken by Professor Sargent as the type of a new species, Populus Palmeri. The principal object of my present visit was to try to rediscover this tree and secure additional specimens of the leaves and a sample of the wood. 
Leaving Uvalde on the motor bus I arrived about two o'clock in the afternoon at a point on the highway opposite the bluff and about two miles distant from it. Making my way across the rocky plain I crossed the river, which although running swiftly was shallow and easily fordable at this point near the north end of the bluff. A number of aquatic plants were growing in a spring that issued from the gravel here, and a little lower down and along the margin of the river $I$ found the shrubby Willow, Salix longipes var. venulosa. Below the bluff and protected by it from the scorching rays of the afternoon sun there is a narrow strip of rocky talus, usually bare near the river but with some accumulation of soil and humus higher up. This is occupied by a rather dense growth of trees and shrubs as well as many herbaceous plants, several of which are very local and out of their usual range here. Pecan and the Texas Oak (Quercus texana) were amongst the commonest trees, with Black Willow (Salix nigra var. Lindheimeri) growing close to the river and Celtis reticulata in more exposed places. The Wafer Ash (Ptelea trifoliata var. mollis) and the Spice Bush (Benzoin aestivale) were abundant and both were in fruit. Rubus trivialis was growing amongst the rocks and Clematis Simsii and Vitis Berlandieri were climbing over rocks and bushes. In clefts of the rock near the base of the cliff I found a beautiful scarlet-flowered sage (Salvia Roemeriana) and the little tufted shrub of the Composite family, Laphamia Lindheimeri.

After some search and as I was almost ready to give up the quest I saw in the distance, in the valley and beyond the south end of the bluff, a large tree standing well above the surrounding growth. From its appearance I felt sure that it was a Cottonwood and upon making my way to it I found that it was the tree I was looking for. It is growing in moist alluvial ground near a spring, just below a little bluff on the east side of the river. This tree appears to be the only one of its kind in the vicinity, but it is conspicuous for size amongst the large Pecan trees and other species that surround it. I found some difficulty in reaching the lowest branches, but finally succeeded in getting a few leaves and a small specimen of wood.

May 2nd.

When I was in Uvalde about ten years ago Mr. F. Getsendener, then the editor of a local newspaper, told me of a very large Cottonwood tree he had seen on the Nueces River a few miles from Uvalde. As trees of the genus Populus appear to be so rare in this vicinity I was anxious to see it, thinking it might prove to be the same as the interesting tree found at Chalk Bluff. Mr. Getsendener at that time kindly took me over to the river where he thought the tree was growing and we spent nearly half a day in searching for it, but without success. A few days ago I again met this gentleman in the Post Office here and he at once recognized me and told me that he had been waiting for a chance for these many years to make good in showing me that Cottonwood tree. Accordingly, this morning he took me over to the river in his car and after going as far as the road would permit we left it 
near a ranch house and struck out down the river. The stream winds about in a tortuous course, often dividing its channel along the rocky flood plain, flanked by low banks or bluffs, beyond which is the narrow valley, open in places but elsewhere dissected with ravines and with a more or less dense growth of shrubs and trees. The going is often difficult and it is particularly hard to keep directions. Live Oak, Pecan and Hackberry are amongst the commonest forest trees, with occasional specimens or clumps of Elm (Ulmus crassifolia), Mulberry, Soapberry (Sapindus Drummondii) and Ash (Fraxinus Berlandieriana) and several other species. The Riverbank Walnut (Juglans rupestris), the Desert Willow (Chilopsis linearis) and the Southwestern variety of the Sycamore (Platanus occidentalis var. glabrata) are characteristic species along the rocky flood plain of the present channel of the river.

After we had tramped several miles and my guide was beginning to feel discouraged we at last saw the tree we were in search of close beside the river. It was a very fine large specimen and I was quite willing to accept Mr. Getsendener's opinion, that it was the largest tree in Uvalde county. The trunk, which was somewhat flattened, was more than seven feet (two meters) in diameter, and while we did not have a chance to measure the height, I estimated that it must have exceeded one hundred feet (thirty to thirty-five meters).

On an examination of the specimens, however, I cannot seethat they have the distinctive characters on which Populus Palmeri was based and it probably must be referred to the common and widely distributed Cottonwood of the eastern United States, Populus balsamifera var. virginiana. This species has not been known before from so far south-west in Texas.

\section{Carrizo Springs, Texas, May $3 d$.}

A torrential rain fell in this section yesterday and last night, and $I$ was advised at Uvalde to take the train rather than conveyance over the highways, which was likely to be interrupted by washouts or high water. I was the only passenger on the coach of the mixed train that runs between Uvalde and Crystal City, and the conductor told me that they often made the trip without any passengers, so successful is the competition of motor busses and private cars along the recently improved roads.

The train traveled slowly enough for me to get a very fair view of the country through which we passed and of its vegetation. For several miles the country was comparatively level and covered with a sparse growth of Mesquite trees and various shrubs, amongst which were Yucea Treculeana, Celtis pallida, Ephedra trifurca?, Acacia Wrightii, Mimosa borealis, Opuntia leptocaulis, O. Engelmannii, Condalia obovata, Colubrina texensis, Cercidium texanum and Lycium Berlandieri. Where the surface was a little more rocky, Acacia Berlandieri was common. In the intervals between the widely scattered trees and tufts of spiny shrubs the ground was white and bare and with scarcely a trace of grass or other herbaceous vegeta- 
tion. Such are the typical "pastures" of this part of Texas. However, after the heavy rain a rapid transformation will take place; grass will begin to spring up in the protection of the shrubs and Rain Lilies (Cooperia Drummondii) and a variety of other showy flowering plants will appear.

About twelve miles southwest of Uvalde we crossed the Nueces River, elose to the boundary of Zavalla County. In the vicinity of the stream and along the low rocky bluffs a marked change in the character of the flora was noticeable, both in the size and variety of trees and shrubs. Pecan, Hackberry and Black Willow were as usual the commonest trees, with Cephalanthus occidentalis and Baccharis glutinosa growing abundantly along the margins of the stream. Platanus occidentalis var. glabrata and Juglans rupestris were growing along gravel bars of the river. On a little bluff just beyond the bridge I noticed some tall plants of Leucophyllum covered with a profusion of large pink flowers. This may have been $L$. frutescens, but the flowers appeared to be larger than those seen elsewhere.

As we approached Crystal City the air became redolent with the odor of onions, this being the height of the shipping season. Fields of onions, trucks and wagons loaded with onions, and many cars in the process of loading, in addition to the heaps of decaying onions dumped along the railway impressed, both upon the eye and olfactory nerves of the traveler, the importance of the industry here. The onions, principally varieties of the White Bermuda sort, are grown in fields, by aid of irrigation from artesian wells. Many hundreds of cars are shipped from this point and Carrizo Springs during the season.

May 4th.

This morning I followed the small stream, Carrizo Creek, which lies just east of the town and runs in a southwesterly direction, for several miles. Most of the land in this vicinity is of a fine deep sand, although some of the higher areas are ealcareous and support a xerophytic flora of the chaparral character. A curious little relative of the Mesquite, Prosopis cinerascens, was growing along the railway, probably introduced from farther south. Parkinsonia aculeata was common in sandy fields along the creek and quite conspicuous with its abundance of yellow flowers. In open places there were acres covered with Argemone intermedia, or a closely related species, but with flowers varying on different plants from white through various shades of pink and rose to the deepest wine-color. The Live Oak was also common in the sands and, in places that have not been disturbed by cultivation or too close grazing, there was a rich herbaceous vegetation of peculiar plants. I photographed a large specimen of Salix nigra var. Lindheimeri along the creek and higher up Sapindus Drummondii and Bumelia lanuginosa var. albicans are abundant. The Bumelia looks very distinct from the typical form, which is common farther east, in its narrow leaves, silvery and sericeous on the under surface. In coming up the creek I dug from the sand a large mammoth tooth, which was rather badly decayed. 
This afternoon I collected on the higher ground just south of the town and bordering the creek. The difference in the flora of the two areas is quite marked. The surface here is rocky with clay or gumbo soil, eroding rapidly into ravines on the slopes along the creek. Mesquite is quite abundant and is the only thing that might be called a tree. Yuccas and Opuntias are conspicuous features and there are many of the smaller Cacti, such as Echinocereus and Mamillaria, growing under the chaparral which, in places, is dense and impenetrable. Some of the characteristic species are Rhus microphylla, R. trilobata, Cercidium floridum, Acacia Greggii, A. Wrightii, Condalia obovata, C. lycioides and Forestiera angustifolia. A curious little Agave (A. maculosa) was in bloom in rocky places and I secured a photograph of it and of several other things.

San Antonio, Texas, May 9th.

In coming up on the railway from Carrizo Springs a few days ago, we passed through some sandy country near the boundary of Frio and Medino Counties where an interesting flora with Oaks and Hickories attracted my attention. With the purpose of exploring this locality I went down on the Laredo motor-bus this morning and got off at the little town of Moore, in northern Frio County. From this place I followed the railroad to Divine, Medino County, collecting on both sides as I went.

Quercus marilandica, Q. stellata, Q. virginiana, Carya Buckleyi and Xanthoxylum Clava-Herculis var. fruticosum are common arborescent species, and Lantana Camara and Bernhardia myricaefolia are growing as undershrubs. The Hickory has a somewhat different appearance from that of the species as it grows farther east, due to the fact that here the branches extend nearly to the ground. I remember finding the same tree near Fredericksburg, Gillespie County, several years ago. Both localities are very near the 99th meridian, and this appears to be about the western limit of its range.

Along the railway enclosure, where grazing is restricted and the woody plants have been cleared away, there is an abundant growth of herbaceous plants and grasses, one of the most conspicuoous species being Phlox tenuis. Along the banks of a little stream, on ground that is flooded after rains and remains muddy for some time, I found Marsilia macropoda growing very luxuriantly.

Blanco, Texas, May 11th.

The village of Blanco, situated near the head of the Blanco River, in the county of the same name, is one of the oldest settlements in this part of Texas, and it has been but slightly touched by modern progress, being more than twenty miles from the nearest railroad and somewhat off the more frequented routes of travel. The mail is received from San Marcos, and I secured a passage today on the truck that renders this service to the town and also to the few rural patrons of the Post Office Department along the road. Between San Marcos and Fischer's Store, a post office and general 
mercantile establishment in Comal County, the road winds through some interesting and picturesque country and over a high limestone ridge, known as the Devil's Back-bone. From the top of this ridge one can look down on either side into deep gorges several hundred feet deep, where there is an abundant growth of small trees and shrubs. Juniperus mexicana is abundant on the hills, and Quercus texana is the commonest deciduous tree. Quercus annulata, Cercis reniformis and Bumelia monticola are also conspicuous. Mahonia Swaseyi was first found by Buckley not far from here, and I collected it here also several years ago; I saw a few specimens of this rare species along the road today, with an abundance of pink fruit.

After securing lodging and getting lunch at the small hotel at Blanco I started out and followed the river down for about four miles. The river is barely flowing at this dry season and one could cross it almost anywhere without difficulty. Some of the interesting trees and shrubs seen along this part of the river are Salix longipes var. venulosa, Ulmus americana, $U$. fulva, U. crassifolia, Celtis laevigata var. texana, Morus rubra, M. microphylla, Mahonia trifoliata, Crataegus Traceyi, Prunus mexicana, P. Reverchoni, P. serotina, Acacia Wrightii, Mimosa Lindheimeri, Eysenhardtia amorphoides, Sophora affinis, Dalea frutescens, Ptelea trifoliata, Rhus virens, $R$. rhombidea, $R$. copallina var. lanceolata, Ilex decidua, Ungnadia speciosa, Aesculus discolor var. flavescens, Malus ioensis var. texana, Ceanothus ovatus, Condalia obovata, Garrya Lindheimeri, Cornus asperifolia, Arbutus texana, Diospyros texana, Fraxinus texensis, Forestiera pubescens, Callicarpa americana, Lonicera albiflora and Eupatorium ageratifolium. This by no means complete list shows a curious mingling of species from the eastern or Carolinian and southwestern, Sonoran, floras.

May 12th.

Having a few hours this morning before starting back for San Marcos I went up the river for a distance of about three miles. In addition to many of the things mentioned yesterday I collected Vitis monticola, which was in full bloom and was climbing to a considerable height in trees. About a mile above the town I found a group of several large trees of Populus balsamifera var. virginiana. Mimosa borealis was abundant, growing as a low spreading shrub, some of the plants being in full bloom and others covered with immature fruit, probably representing a response to two rains occurring a few weeks apart.

Low bluffs occur at intervals on either side of the river; these are seldom more than eight or ten meters high and of no great length, the soft limestone strata breaking down rather rapidly under erosional agencies. There are many well preserved fossils in some of the beds and in the clay partings between them, which seem to belong to the Fredericksburg group of the Comanchean series; sometimes this is overlaid with a conglomerate deposit. These bluffs afford a habitat for a variety of woody as well as herbaceous plants, many of which are found only in their protection. Two species of Linden (Tilia caroliniana and $T$. floridana) are amongst the 
most interesting trees of such situations, and curiously they occur usually, if not always, along bluffs of the north side of the river, or those with a south exposure. As the river usually flows at the immediate foot of the bluff, a possible explanation is that a greater amount of evaporation in such situations tends to keep the air moist and more than offsets the direct heat. Prunus Reverchoni, Rhus rhomboidea, Ungnadia speciosa, Garrya Lindheimeri and Sambucus canadensis also grow in the protection of the bluffs, and where there is considerable moisture or seepage water from ledges, Rubus trivialis is likely to be found and often a luxuriant growth of Maidenhair Fern (Adiantum Capillus-Veneris).

One of the highest cliffs is known as Red Bluff and it was at this point that I turned back. This bluff is quite heavily wooded and there are some deep pools of water along its base. Several Linden trees were seen on the steep rocky slopes and here also Prunus serotina var. eximia and Ulmus fulva were growing, with Cornus asperifolia and Sambucus near the base. On the opposite side along the margins of a deep pool were several trees of the bald Cypress (Taxodium distichum), another southeastern species and usually an inhabitant of swamps, which seems strangely out of place in this semi-arid region.

\section{Big Spring, Texas, May 17th.}

Heavy rains fell last night and this morning while we were on the train coming over from Sweetwater. This must have reached almost the proportions of a "cloud-burst" here, as such torrents are known in this section. When we arrived at the station it was still raining sharply and the tracks, platform and all of the surrounding low grounds were flooded.

The rain having abated this afternoon, I started west on the railway to reach the outskirts of the town, thinking that the dryest way. However, I had not calculated on the extent of the flood and I had to go two or three miles before $I$ could find a place to cross the small river that was racing down the ditches that paralleled the embankment. Finally, wading water knee-deep and making my way across a muddy flat for some distance, I managed to reach higher ground. The railway and the lower part of the town occupy a creek valley and all of this was flooded. To the west, at the point where I left the valley, there is a dry sandy plain gradually rising to a bold escarpment about a mile beyond.

Red sandy soil with considerable gravel, and probably impregnated with gypsum, as it appears to belong to the Permian formations, covers the surface of the plain. It is occupied by a shrubby flora, rather dense in places, and elsewhere with wide bare spaces in which a few herbaceous perennials struggle to maintain an existence. Characteristic shrubs are Juniperus Pinchotii, Ephedra antisyphilitica, Mahonia trifoliata, Prosopis juliflora, Atriplex canescens, Mimosa fragrans, Covillea tridentata, Condalea obovata, Koeberlinia spinosa, Microrhamnus ericoides, Rhus microphylla and Opuntia leptocaulis. Juniperus Pinchotii grows here as a shrub seldom more than four or five meters high. It has much the habit of Juniperus 
monosperma, but can readily be distinguished from that species by its stouter branchlets and generally stiffer habit, even in the absence of the large copper-colored fruit. The Creosote Bush (Covillea) has a monopoly of some of the more sterile and flat portions but with it sometimes grows Koeberlinia spinosa, presenting a very curious appearance with its green naked thorny branches.

There had probably been some rain shortly before the present heavy fall, since many of the shrubs were in flower and the little yellow-flowered Rain Lily, Atamosco texana, Cassia pumilio and a few other herbaceous plants were in bloom.

On the limestone hills there was an almost complete change in the character of the flora. A shrubby growth of Quercus Mohriana occupied the steep slopes and ledges and base of the eliffs; Celtis laevigata, Xanthoxylum Clava-Herculis var. fruticosum, Rhus trilobata, Ungnadia speciosa and Bumelia monticola also grew here.

There is a driveway to the top of this plateau or mesa, which overlooks the town, and from which an excellent view of the latter and of the surrounding country may be had. Following this, I came down to the railroad again on the east side of the town and after wading more mud and water came out again on low calcareous hills and a mile or two farther east got into an area of deep loose sands with quite another type of vegetation.

Quercus Havardi was very common here, growing in clumps or thickets, and usually as a slender shrub one to rarely two meters in height. It appeared very distinct from Quercus Mohriana of the limestone hills, but along the contact of the two formations there were some very puzzling forms, that suggested either hybridization or the possibility that the two extremes might be ecological responses to the different environment. Artemisia filifolia was also common in the sands, and a little shrubby Pentstemon (P. ambiguus) was in full bloom. The latter had a profusion of pale lavender blooms and was one of the most conspicuous and showy plants I have seen in this region. Amongst herbaceous species Dithyraea Wislizeni was very abundant, and Houstonia humifusa, Anogra albicaulis, Monarda clinopodioides and Hymenopappus corymbosus were conspicuous. Yucca constricta was in full bloom and I made photographs of this and of several of the other plants.

\section{Pecos, Texas, May 18th.}

After exploring the Pecos River along the last few miles of its course and its junction with the Rio Grande, I was anxious to see it farther up and learn how the flora at this point compares with that of the lower canyons. The contrast is certainly striking but so far as the flora is concerned it is also disappointing. The surrounding country is all rather level and the surface is sandy and the soil strongly gypsous and saline. In consequence it is extremely sterile and in many spots absolutely devoid of plant life. A few stunted Mesquite bushes are the only ligneous plants over wide areas. Both the glabrous and pubescent varieties were noted. The soil appears 
generally to be too poor even for Cactus, although a few discouraged looking specimens of Opuntias and a small Echinocereus were seen. In a few places Lippia lanceolata and Lepidium alyssoides were blooming bravely and plants of Statice Limonium were coming up. Along the banks of the river, however, one tree is abundant and conspicuous and serves to relieve the dreary monotony with its bright green foliage, This is Tamarix gallica, the Salt Cedar, a native of the Mediterranean region, which has been introduced and thoroughly established in this part of Texas. It lines the low banks of the river here for miles and appears to flourish everywhere along ditches and ponds or wherever there is a little moisture.

The list of woody plants here is a very short one; besides those just mentioned I saw a few specimens of Condalia obovata and Lycium Torreyi, and Allenrolfea occidentalis was locally abundant in flats and depressions.

\section{NOTES}

The Arnold Arboretum during the Fiscal year ended June 30, 1928.

The Arboretum.-In Massachusetts the winter of 1927-28 will be remembered for its mildness and absence of heavy snowfalls and while ground covering plants suffered on this account the trees and shrubs in general were uninjured. During the autumn of 1927 and the spring and early summer of 1928 good rains fell and the Arboretum shows the benefit of two successive favorable years. It is many years since the plants have been so well favored. The Lilacs, which were severely pruned in the spring of 1927 , made great growth and many of them flowered quite freely this year. The trusses of flowers were remarkably large but no increase in the size of the individual blossom was noticeable. This is rather curious since one would have expected increased size in the flower as well as in the flower truss and in the leaf itself. The Japanese Cherries at the Forest Hills Gate flowered as freely as usual, while the double flowering sorts on Bussey Hill were finer than they have ever been before. There is a difference of more than a fortnight in the flowering season of these two groups which adds greatly to their value in gardens. The collection of double flowering varieties on Bussey Hill is grafted on understocks of the Sargent Cherry (Prunus serrulata sachalinensis) and the trees clearly demonstrate the value of this species as an understock for the Japanese Cherries. The Crabapples, more especially the collection at the foot of Peters Hill, bore abundant blossoms and for the first time in the Arboretum the two plants of Malus theifera and two plants of Malus toringoides flowered freely. Heretofore, one of the plants in each case has enjoyed an off season. There was very little blossom on the Kalmias this year but the Hybrid Rhododendrons were better than usual. They wintered fairly well after having made a good growth the previous season.

The winter was marked by a very low snowfall and this had a disastrous effect on the dwarf evergreen plants familiarly called groundcovers. In 


\section{$2 \mathrm{BHL}$ Biodiversity Heritage Library}

Palmer, Ernest J. 1928. "Leaves from a Collector's Note Book." Journal of the Arnold Arboretum 9(4), 173-187. https://doi.org/10.5962/p.185196.

View This Item Online: https://www.biodiversitylibrary.org/item/33587

DOI: https://doi.org/10.5962/p.185196

Permalink: https://www.biodiversitylibrary.org/partpdf/185196

\section{Holding Institution}

Missouri Botanical Garden, Peter H. Raven Library

\section{Sponsored by}

Missouri Botanical Garden

\section{Copyright \& Reuse}

Copyright Status: In copyright. Digitized with the permission of the rights holder.

Rights Holder: Arnold Arboretum of Harvard University

License: http://creativecommons.org/licenses/by-nc-sa/3.0/

Rights: https://biodiversitylibrary.org/permissions

This document was created from content at the Biodiversity Heritage Library, the world's largest open access digital library for biodiversity literature and archives. Visit BHL at https://www.biodiversitylibrary.org. 